\title{
TEACHER PROFESSIONALISM IMPROVEMENT MANAGEMENT: STUDY OF PRINCIPAL LEADERSHIP AT SMA AL-ITTIHAD KARANG TENGAH CIANJUR
}

\author{
Undang Ruslan Wahyudin', Dudung Winara'2 ${ }^{\text {, Hinggil Permana }}{ }^{3}$ \\ 1,3Islamic Education Department, Universitas Singaperbangsa Karawang, West Java, Indonesia \\ ${ }^{2}$ Akademi Kebidanan Alikhlas Cisarua, Karawang, West Java, Indonesia \\ Email : urwahyudin@fai.unsika.ac.id ${ }^{1}$, dudungwinara@gmail.com², \\ hinggil.permana@fai.unsika.ac.id ${ }^{3}$
}

DOI: http://doi.org/10.33650/al-tanzim.v5i2.2222

\begin{tabular}{l|l|l} 
Received: June 2021 & Accepted: August 2021 & Published: August 2021
\end{tabular}

\begin{abstract}
:
This research is motivated by the fact that at Al-Ittihad High School, there is a lack of awareness of students towards the practice of religion. This study aimed to determine the principal's program in planning, organizing, implementing, supervising, supporting, and inhibiting factors from improving the professionalism of teachers at Al-Ittihad High School. This research is qualitative descriptive field research. They are collecting data using interviews, observation, and documentation methods. Analysis of the data used is a qualitative analysis consisting of three components of analysis: data reduction, data presentation, and concluding. All three are carried out interactively with the data collecting process as one cycle. The results show that planning is done by improving the quality of teachers, continuing education to a higher level, providing adequate honorarium incentives, involving teachers in training, workshops, seminars, workshops, and so on.
\end{abstract}

Keywords: Teacher Professionalism, Principal Leadership, Supervision

Abstrak:

Penelitian ini dilatarbelakangi oleh fakta bahwa di SMA Al-Ittihad masih rendahnya kesadaran siswa terhadap pengamalan agama. Tujuan penelitian ini adalah untuk mengetahui program kepala sekolah dalam perencanaan, pengorganisasian, pelaksanaan, pengawasan serta faktor pendukung dan penghambat upaya peningkatan profesionalisme guru di SMA Al-Ittihad. Penelitian ini merupakan penelitian deskriptif kualitatif di lapangan. Pengumpulan data menggunakan metode wawancara, observasi dan dokumentasi. Analisis data yang digunakan adalah analisis kualitatif yang terdiri dari tiga komponen analisis, yaitu reduksi data, penyajian data, dan penarikan kesimpulan. Ketiganya dilakukan secara interaktif dengan proses pengumpulan data sebagai satu siklus. Hasil penelitian menunjukkan bahwa manajemen dilakukan dengan cara meningkatkan kualitas guru, melanjutkan pendidikan ke jenjang yang lebih tinggi, memberikan insentif honorarium yang memadai, mengikutsertakan guru dalam pelatihan, workshop, seminar, workshop dan sebagainya.

Kata Kunci: Profesionalisme Guru, Kepala Sekolah, Supervisi 


\section{INTRODUCTION}

In simple terms, Islamic education is a process of transinternalizing Islamic knowledge and values to students through teaching, habituation, guidance, nurturing, monitoring, and developing their potential, to achieve intelligence and perfection of life in this world and the hereafter. Based on this limitation, education contains at least five critical elements, namely; 1) efforts in islamic education are carried out in stages, tiered, planned, structured, systemic, and continuously using transformation and internalization of islamic knowledge and values to students; 2) the material given to students is islamic knowledge and values, namely knowledge and values derived from god (ilahiyah); 3) education is given to students as subjects and objects of education; 4) the main task of education is to provide teaching, habituation, guidance, nurturing, monitoring, and developing the potential of students to form and develop their creativity and productivity without neglecting their essential potential; 5) the ultimate goal of islamic education is the creation of insan kamil (perfect human). Another opinion says that Islamic education is guidance given by someone to develop optimally through Islamic teachings. In short, Islamic education is advice for someone to become a Muslim as much as possible (Wahyudin et al., 2020). Education is an effort to develop individual talents and abilities to actualize their mental potentials fully. These potentials are a precious wealth in humans (Silviani et al., 2021).

The research conducted by Sari et al., (2020) mentioned if a teacher's professionalism can not be separated from the support and efforts made by a madrasah head. The role of the Head of madrasah leadership in improving the professionalism of teachers is vital. To achieve the vision with one of these missions, a teacher as an educator must carry out his duties professionally. This is in line with the research conducted by Maulana (2019), which states that the leadership of the Head of the madrasah to improve the professional competence of teachers can be seen from the planning of the leadership strategy of the Head of the madrasah, not an easy thing, the knowledge of the principal about the plan, professional competence of teachers, the competence of teachers should be mastered entirely by the Head of the madrasah

Amirudin (2017) also reinforces this if the principal's leadership is very influential to teachers in all aspects. While what is done in this research is about the principal's leadership in managing to improve the professionalism of teachers in the Institution in the pesantren environment, which will certainly differ from the various asfek how the principal conducts management to enhance the professionalism of his teachers.

On the other hand, the consequences of this recognition must be paid for with maximum productivity targets and quality, both IMTAK and science and technology. In achieving these targets, management functions such as planning, organizing, managing, coaching, monitoring, and evaluating must be applied and reflected in every element of the madrasa, such as curriculum, administrators, students, especially teachers as educators. Education in madrasas is education that is deliberately established and carried out with a desire and intention (an actual plan) to embody the teachings of Islamic values, 
as stated in the vision, mission, goals, program of activities, and practice of educational implementation (Wahyudin et al., 2021). Madrasah is one of the schools that aims to develop Islamic education. This is where the principal has a role as a decision-making center to determine the system of rules for implementing education and achieving school goals that have been selected together. At the same time, the teacher is the spearhead of implementing the decisions and policies set by the principal. According to Islam, the performance of religion (based) education is worship's command, which is worship (Nurmiyanti \& Candra, 2019).

The principal is an educational leader at the education unit level who must have a strong leadership base. Educational leadership is concerned with the principal's increasing opportunities to meet effectively with teachers in conducive situations. Positive principal behavior can encourage, direct, and motivate all school members to work together in realizing the school's vision, mission, and goals (Permana, Syafrida, 2019).

However, the educational problem faced by the Indonesian people is the low quality of education at every level, type, and unit of instruction. Several facts show that the quality of our education is still low, this can be seen compared to other countries. The United Nations Development Program (UNDP) in its Human Development Report 2016 noted that Indonesia's Human Development Index (HDI) in 2015 was ranked 113, down from 110 in 2014 (Supriadi, 2001). The low quality of Indonesian education is also reflected in the difficulty of changing job search. Schools are the foremost institutions in carrying out the educational process. Macro education will ultimately lead to schools through learning. The principal plays a vital role in moving the various components in the school so that the teaching and learning process at the school runs well (Maryati, K. Suhandi, \& Permana, 2020).

Based on an interview with the Vice-Chancellor of Student Affairs, the realization of religious culture at SMAAl-Ittihad is motivated by students' lack of awareness to the practice of religion. For example, when performing fardu prayers in congregation, they must always be called upon by the person in charge of the hostel; when the recitation program started, he came late, sometimes staying in his room; when asked to get used to reading the Koran, there are still many students who are lazy to read it; and in addition, there are many students who are still naughty, starting from scribbling on the walls of the school with bad words, even in speaking there are still students who violate the rules. The research focused on the management used by the principal in improving the professionalism of teachers.

\section{RESEARCH METHODS}

Research is fact-finding according to a precise objective method to find facts and produce propositions or laws. The research method referred to here is the method used in the study, including research approach, discovery of research locations, sources and data collection, data validation, and data analysis. To obtain substantive research on this research is descriptive research using a qualitative approach (Sugiyono, 2016). 
The method used in this research is the descriptive qualitative method. The descriptive qualitative study seeks to systematically and accurately sense or observe problems systematically and accurately regarding specific facts and objective characteristics. Descriptive analysis is intended to describe and describe and map points based on a particular perspective or frame of mind. This method seeks to describe and interpret what exists; it can be about existing conditions or relationships, growing opinions, ongoing processes, consequences or effects that occur, or developing trends.

Primary data sources in this study are matters related to the management of teacher professionalism improvement in schools based on leadership performance that has been running and received positive responses from the community; the data were obtained from the Chair of the Foundation, Principals, Teachers and Education Personnel, and Students Al-Ittihad High School Karangtengah Cianjur. At the same time, secondary data is data obtained from official documents, books, previous research results in the form of reports relevant to research problems, and so on. Secondary data obtained by researchers directly from related parties, such as vision, mission, school strategic plan, archives, etc. As well as various literature relevant to the discussion of research on Management of Teacher Professionalism Improvement (study of principal leadership at SMA Al-Ittihad Karangtengah Cianjur).

\section{FINDINGS AND DISCUSSION}

\section{Principal Planning in Improving Teacher Professionalism}

Planning is making decisions concerning actions that will be followed by other companies (Wahyudin, 2021). Before making a decision, we must first review the plan, analyze it or submit a proposal. Planning is concerned with what to do, how to do it, when to do it, and who. The human resources needed by the organization or institution must be planned. This is to get the human resources that the institution needs to achieve the goals that have been determined (Zulkarnain et al., 2020). The achievement of the institution's goals is primarily determined by the quality of the human resources owned by the institution. Therefore, the role of planning becomes something important (Althof \& Berkowitz, 2006). Good planning will help get qualified human resources. This is generally related to resources that are suitable for learning needs that are held in the long term (Katilmiş et al., 2011).

What has been done by the Al-Ittihad High School principal to improve the quality of teacher professionalism is to strive for them to continually improve their quality by continuing their education to a higher level according to their talents and expertise and by their academic qualifications. In addition, school principals strive to provide high honorariums and incentives to educators so that the welfare of their families is fulfilled economically, which in the end, they will be more focused on their duties and obligations as educators. This is done so that educators no longer teach at other educational institutions because schools prioritize graduate competency standards that have been contained in the school's vision, mission, and strategic plans. 
Based on interviews with the principal in educational training, such as seminars, workshops, workshops, symposia, and others directly or indirectly related to the world of learning in schools, including good school governance. They attended these activities, whether organized by the Department of Education and Culture for Elementary and Secondary Education or those organized by the Ministry of Religion in charge of Islamic education or perhaps other institutions that held the training in question. This is done to adapt contemporary science and knowledge, as government policies change every year and adapt to the increasingly unstoppable level of progress and technology. Therefore, educators are expected to be literate in science and today's technological developments. Otherwise, schools will not be able to realize their quality to answer doubts in the community.

Furthermore, the teaching staff at Al-Ittihad High School were included in the Subject Teacher Consultation forum (MGMP), which was adjusted to their respective subjects. These efforts make it easier for them to absorb information from policymakers or existing stakeholders so that they become reference materials to improve the quality of learning in schools. With mutual coordination between teachers of fellow-subjects from different schools, the sense of unity creates a relationship to remind each other to become professional teachers in their fields.

\section{Organizing the Principal in Improving Teacher Professionalism}

People work together to achieve a specific goal; they must have their respective roles, like the actors in a drama (Wahyudin et al., 2021). Whether this role was developed by themselves or determined by someone else is a mere coincidence. This role is needed so that everyone can contribute to the group. This role means that what a person does has a specific purpose; whether the results of their work match the needs of the group; where they get the authority to do the work, and where they can get the tools and information to get the job done. Including organizing is; 1) It is determining activities that can be used to achieve goals; 2) grouping these activities into departments or sections; 3 ) Tasks that managers must complete; 4) Representatives of authorities to carry out tasks; 5) Provisions to coordinate assignments, authority, and information horizontally and vertically in the organizational structure.

According to the principal of Al-Ittihad High School, the strategy for sustainably developing teacher professionalism can be carried out with various methods, including the following: First, participate in competency-based training. A form of exercise that focuses on specific skills needed by teachers to carry out their duties effectively. This training is suitable to be carried out in one form of pre-service or in-service training. Based on interviews with teachers, this training model is different from the conventional training approach because the emphasis is more on evaluating the actual performance of a particular competency of the trainees. 
Second, participate in traditional training courses and programs (including further education). In-service workshops, seminars, undergraduate/postgraduate level lectures, conferences are forms of training options that have been around for a long time and are recognized as valuable. However, it is recognized that it is often the case that these various forms of traditional courses/training are often unable to meet the practical needs of the teacher's work. Therefore, a combination of academic material with field experience will be very effective for developing this traditional course/training. Meanwhile, as part of conventional training, teachers can build their professionalism through further education at universities/LPTKs.

Third, read and write journals or other scientific papers. Journal of other scientific papers are continuously produced by individual authors, educational institutions, and other institutions. Journals or other forms of scientific work are scattered and can be found in various learning resource centers (libraries, internet, and so on). Although articles in journals tend to be brief, they lead readers to new concepts and perspectives for further planning and research. It also has a news column related to meetings, exhibitions, seminars, educational programs, and so on that may be of interest to teachers. Therefore, by reading and understanding many journals or other scientific papers in education related to the teaching profession, teachers can naturally develop their professionalism (Handoko, 2016). Furthermore, with increasing knowledge and growing experience, teachers may be able to build new concepts, special skills, and learning tools/media to contribute to people of one profession or another profession in need. This contribution is possible in writing scientific articles/papers that are very useful for the professional development of the teacher concerned and others.

Fourth, participate in scientific conferences or meetings. Scientific conferences or meetings provide an essential meaning for keeping up-to-date matters relating to the teaching profession. The primary purpose of most scientific conferences or seminars is to present the latest information and innovations in a particular field. A minimum participation of teachers in scientific conferences or meetings every year will contribute to building teacher professionalism in carrying out their responsibilities in delivering primary papers, small group discussion activities, scientific American, meeting information to exchange ideas or new ideas, and so on to integrate. To provide opportunities for teachers to lead or be presenters and exchange ideas with others so that teachers will become more active in their scientific community. In addition, attending scientific conferences or meetings also allows teachers to build cooperative networks with other people who are professional or not to exchange problems and achieve success.

\section{Implementation of the Principal in Improving Teacher Professionalism}

Organizing influences other people so that they want to try sincerely and enthusiastically towards the goals to be achieved by the institution/institution; this leads to concerns the interpersonal aspects (interpersonal) in management (Winardi, 2004). The obstacles in leading are the desires and attitudes of 
different people, their attitudes both as individuals and groups, and the need for managers to become influential leaders. The professionalism of teachers at Al-Ittihad High School in learning is carried out by increasing several owned and attached competencies to them to reflect in the implementation of the teaching and learning process. For a teacher's ability to improve, efforts are needed to perfect his professionalism, including Islamic Religious Education teachers. The demands for applying Islamic teachings are constantly growing; if the teacher does not improve his abilities, he cannot answer the needs and problems in society. Improving the quality of teacher professionalism implemented at Al-Ittihad High School is carried out in several ways: Improving Educational Qualifications. One of the principles of implementing the teaching profession as described in Article 7 of Law 14 of 2005 concerning teachers and lecturers is to have the opportunity to develop professionalism sustainably through lifelong learning. This understanding that a teacher should not be satisfied with the knowledge he already has felt enough with what he has mastered now. To provide teaching, the teacher must also learn from the process to perfect any existing deficiencies.

In addition, teachers are also required to improve higher education levels; currently, what is needed for the government for teacher qualifications is if someone already has a diploma from LPTK (equivalent to S1) or has a teaching certificate. Not only does it stop at that level, but teachers must also be required to continue their education to the S2 or S3 level. The phenomenon that occurs in educational science, especially the problems of teachers and students, is the lack of teacher motivation to conduct scientific studies or research in education. It is more striking if the teacher himself raises educational problems in the learning process into scientific research. Currently, teachers who teach at Al-Ittihad High School are doing various ways to improve their quality of teaching. This effort is carried out by participating in every training and seminar on education, both held by schools, from the district and national levels

\section{Principal Supervision in Improving Teacher Professionalism}

Controlling is measuring and improving the work done by subordinates so that they do not deviate from their original goals (Althof \& Berkowitz, 2006). Here we must determine what negative things or deviations can hinder the purpose; then, we must correct these mistakes and help ensure that the plan has been completed. Although planning is earlier than controlling, the planning cannot be produced by itself. Planning is a guide for managers in achieving goals. Then the plan's implementation must be reviewed, whether by the original intent or not (Permana et al., 2021).

Based on interviews with teachers periodically, the principal of the AlIttihad High School carefully examines the reports prepared by the teachers who carry out the planning as stated above. Teachers' reports are often a source of encouragement for teaching staff to violate integrity. In another context, psychological demands or urges to give a favorable report to superiors often undermine the personal integrity of the school community they lead. If the principal takes no prevention efforts, this, in turn, will threaten the integrity of 
the institution or the school as a whole.

Careful teaching staff can find out whether or not their principal is qualified immediately. Therefore, they are an essential source of information for school principals to know the actual quality of their closest assistants. The teaching staff who are brilliant in the principal's eyes are not necessarily so in the eyes of the teaching staff. Input from teachers is significant for school principals, especially about personnel evaluation. Although formally, this method is less practical or challenging to implement, essential lessons are contained here. The feedback mechanism is no less important as a valuable source of information for school principals regarding teachers' quality, character, and behavior.

In conducting monitoring and evaluation related to increasing teacher professionalism, the principal of Al-Ittihad High School is carried out regularly to ensure the effectiveness of implementation. Monitoring and evaluation are carried out in stages and continuously. The results of monitoring and assessment reflect the point of teacher professionalism carried out in schools. The results are used to improve the quality of the implementation of enhancing the professionalism of the following teacher or in the future or the next learning year.

Monitoring and evaluation is a strategy to determine whether increasing teacher professionalism is by the expected goals (Arifin et al., 2020). In addition, through this activity, problems can be identified and recommendations to overcome them. The analysis process in the evaluation is directed at concluding the success of teacher professionalism to map the performance of a professional teacher.

\section{Barriers and Support in Improving Teacher Professionalism}

Based on interviews with the principal, two factors can support teachers in realizing their performance as professional teachers, namely internal and external. Internal factors: teacher education level, personality and dedication, teaching ability, discipline, teacher education level, personality and dedication, teaching ability, discipline. External factors: facilities and infrastructure, welfare guarantee, managerial ability of the principal, relations with the community, facilities and infrastructure, welfare guarantee, principal managerial ability, community relations.

Internal obstacles that come from the teacher itself, such as a lack of motivation in teaching, parents, or the community environment, are also sometimes an obstacle, which means that support from the community will help teachers realize professional performance. Similarly, the supervision of the principal is not maximal, causing the teacher to be negligent in carrying out his duties. Supporting factors in improving the professionalism of teachers at AlIttihad High School are adequate teacher education level, undoubted personality and dedication, teaching skills that are by their field, and discipline. External factors hinder the lack of facilities and infrastructure, no health insurance for teachers, and managerial abilities of incompetent principals because the educational qualifications are still undergraduate. Relations with 
the community are also poorly maintained because it is in one complex. If everything is resolved, it will support the creation of improved teacher professionalism. The Principal Working Group accommodates efforts to strengthen support and remove obstacles made by the principal by fostering his professional skills through communication with other principals. In addition, the principal also seeks to improve teacher welfare so that teachers also try to focus on one school where the majority of educators teach in several schools. The headmaster performs his functions adequately and appropriately and performs all managerial components in the school.

\section{CONCLUSION}

The principal's plan to improve teacher professionalism at SMA AlIttihad Karangtengah Cianjur is to launch a program to improve teachers' quality, continuing education to a higher level, provide adequate honorarium incentives, and involve teachers in training, workshops, seminars, workshops, and so on. Organizing school principals in improving teacher professionalism at SMA Al-Ittihad Karangtengah Cianjur actively participates in challenging and exciting activities, builds good relations with the community, and has the ability and experience in the context of educational development. Implementation of the principal in improving the professionalism of teachers at SMA Al-Ittihad Karangtengah Cianjur by increasing academic qualifications. Supervision of the principal in improving the professionalism of teachers at SMA Al-Ittihad Karangtengah Cianjur periodically the principle of SMA AlIttihad examines carefully the reports prepared by the teachers who carry out the planning. It is carried out regularly, gradually, and continues to ensure the effectiveness of the implementation of learning.

\section{REFERENCES}

Althof, W., \& Berkowitz, M. W. (2006). Moral Education and Character Education: Their Relationship and Roles in Citizenship Education. Journal of Moral Education, 35(4), 495-518. https://doi.org/10.1080/03057240601012204

Amirudin. (2017). Kepemimpinan Kepala Madrasah dalam Meningkatkan Kedisiplinan Guru. Al-Idarah: Jurnal Kependidikan Islam, 7(2), 23-37.

Arifin, Z., Kosim, A., Muzaki, I. A., \& Permana, H. (2020). Concept and Implementation of Character Education for Urban Children and Adolescents Viewed from the Perspective of the Quran Surah Luqman Verses 12-14. 10(2), 95-102.

Handoko, T. H. (2016). Manajemen Personalia dan Sumber Daya Manusia. Jakarta: BPFE

Katilmiş, A., Ekşi, H., \& Öztürk, C. (2011). Efficiency of social studies integrated character education program. Kuram ve Uygulamada Egitim Bilimleri, 11(2), 854-859. 
Maryati, M., Suhandi, T. K., \& Permana, H. (2020). Character Education Program for Student in Islamic Boarding School. KnE Social Sciences, 638647. https:// doi.org/10.18502/kss.v4i14.7921

Maulana, T. (2019). Strategi Kepemimpinan Kepala Madrasah untuk Meningkatkan Kompetensi Professional Guru PAI. Jurnal Tahdzibi: Manajemen Pendidikan Islam, 4(1), 55-66. https://doi.org/10.24853/tahdzibi.5.2.145-156

Nurmiyanti, L., \& Candra, B. Y. (2019). Kepemimpinan Transformasional dalam Peningkatan Mutu Pendidikan Anak Usia Dini. Al-Tanzim: Jurnal Manajemen Pendidikan Islam, 3(2), 13-24. https://doi.org/10.33650/altanzim.v3i2.646

Permana, H., \& Syafrida, R. (2019). Meningkatkan Keterampilan Mengenal Huruf hijaiyAh melalui Metode Utsmani dan Metode Baghdadi. Awlady: Jurnal Pendidikan Anak, 5(02), 48-62.

Permana, H., Fauzi, I. A. H., Hasanah, A., \& Arifin, B. S. (2021). Pengembangan Model Manajemen Pendidikan Karakter di Sekolah. Muntazam: Jurnal Manajemen Pendidikan Islam, 2(01), 41-55.

Sari, N., Hamengkubuwono, \& Mustar, S. (2020). Peran Kepemimpinan Kepala Madrasah dalam Meningkatkan Professionalitas Guru. Manajemen Pendidikan Islam, 3(2), 200-216. https:/ / doi.org/10.30868/im.v3i02.852

Silviani, S., Maarif, M. A., \& Wibowo, A. (2021). Knowledge Sharing Management: Strategy for Improving the Quality of Human Resources. Al-Tanzim: Jurnal Manajemen Pendidikan Islam, 5(1), 129-139. https://doi.org/10.33650/al-tanzim.v5i1.1831

Sugiyono. (2016). Metode Penelitian Pendidikan (Kuantitatif Kualitatif dan $R \mathcal{E} D$ ). Bandung: Alfabeta.

Supriadi, F. J. \& D. (2001). Reformasi Pendidikan dalam Konteks Otonomi Daerah. Yogyakarta: Adi Cita.

Wahyudin, U. R., \& Permana, H. (2020). Education Quality Assurance Management in the Faculty of Health Science, Singaperbangsa Karawang University. KnE Social Sciences, 505-512.

Wahyudin, U. R. (2021). Implementasi Manajemen Pendidikan Berbasis Masyarakat dalam Penjaminan Mutu Pendidikan Anak Usia Dini. Jurnal Obsesi: Jurnal Pendidikan Anak Usia Dini, 6(2), 652-663.

Wahyudin, U. R., Permana, H., Nurlailasari, E., \& Mustofa, T. (2021). Sosialisasi Model Manajemen Pendidikan Berbasis Masyarakat di Pondok Pesantren Syekh Quro Kabupaten Karawang. Abdi Dosen: Jurnal Pengabdian Pada Masyarakat, 5(2), 220-226.

Winardi. (2004). Manajemen Perilaku Organisasi. Jakarta: Pustaka Binaman Pressindo.

Zulkarnain, A. I., Supriadi, G., \& Saudah, S. (2020). Problematika Lembaga PAUD dalam Memenuhi Kebutuhan Tenaga Pendidik Sesuai Kualifikasi. Jurnal Obsesi: Jurnal Pendidikan Anak Usia Dini, 5(1), 14. https://doi.org/10.31004/obsesi.v5i1.491 